\title{
VARIABELTYPER OG DIKOTOME
}

Viskal se nærmere på hvordan vi kan bruke statistikk når for skjeller og endringer måles på en diskontinuerlig skala.

I tidligere utgaver av Sykepleien Forskning har vi sett nærmere på betydningen av statistiske begrep som populasjon, utvalg, sammenlikning, konfidensintervall, hypotesetest og p-verdier (1-3). Vi har tidligere konsentrert oss om størrelser som kan måles på kontinuerlige skalaer som vekt og avstand, men det er mye som ikke kan måles på en kontinuerlig skala.

\section{> KONTINUERLIGE VARIABLE}

Tenk at du er hos fastlegen og får beskjed om blodtrykket ditt er litt høyere enn det som anses som optimalt. Heldigvis finnes det medisiner som kan bidra til å redusere blodtrykket. Én studie viser for eksempel at ramipril kan redusere systolisk og diasystolisk blodtrykk med henholdsvis $3,8 \mathrm{mmHg}$ og 2,8 mmHg i gjennomsnitt (4). Blodtrykk er eksempel på et mål som måles på en kontinuerlig skala, og selv om en blodtrykksreduksjon er vel og bra vil mange være enig i at lavere blodtrykk ikke er et mål i seg selv. Det å redusere blodtrykket er først og fremst viktig fordi vi håper at lavere blodtrykk skal redusere risikoen for å oppleve alvorlige hendelser som hjerneslag, hjerteinfarkt eller død. Med det er vi over på temaet for denne teksten, for slike hendelser kan ikke måles i meter, kilo eller andre kontinuerlige utfall - hendelsene er med andre ord diskontinuerlige.

\section{> KATEGORISKE VARIABLER}

Selv om vi ikke kan snakke om kontinuitet kan hjerneslag likevel klassifiseres eller telles på ulike måter. Vi kan kategorisere personer som har fått hjerneslag basert på grad av funksjonstap, ofte kalt flerkategorivariabel. Hvis vi derimot stiller spørsmål om hvor mange som har fått påvist et hjerneslag må vi nøye oss med to kategorier, for enten har du fått påvist et hjerneslag eller også har du det ikke.
Dette blir enda tydeligere når vi sammenlikner dødsfall. Enten lever pasienter eller så er pasienten $\mathrm{d} \varnothing \mathrm{d}$. Én og samme pasient kan ikke være både død og levende på ett og samme tidspunkt. Slike «enten eller» tellinger omtales ofte som en to-kategori (dikotom) variabel.

\section{$>2 \times 2$ TABELLER}

Blodtrykkstudien nevnt over er en stor studie der forfatterne fordelte nesten 10.000 pasienter i to grupper som fikk henholdsvis ramipril og narremedisin (4). De målte om blodtrykket endret seg, men registrerte også hvor mange som døde av hjerneslag i hver av de to gruppene mens studien pågikk. Disse resultatene kan oppsummeres av fire enkeltstående tall i en $2 \times 2$ tabell (se tabell 1). Med bare fire tall tilgjengelig skulle en kanskje tro at mulighetene for å drive analyse og tallmagi er begrenset, men som vi skal se kan disse fire tallene kombineres på veldig mange måter og forvolde en del hodebry.

TABELL 1: Eksempel på en $2 \times 2$ tabell basert på resultater $\mathrm{i}$ en randomisert kontrollert studie med 9297 deltakere som unders $\varnothing$ ker om ramipril bidrar til å redusere risiko for hjerneslag og død (4).

Behandling

\begin{tabular}{llcc} 
& & Ramipril & Placebo \\
\hline & $\begin{array}{l}\text { lkke dødav } \\
\text { hjerneslag }\end{array}$ & 4628 & 4608 \\
Status & $\begin{array}{l}\text { Dødav } \\
\text { (Etter 4 år) }\end{array}$ & 17 & 44 \\
\hline
\end{tabular}




\section{EFFEKTMÅL}

\section{> RISIKO}

La oss starte med å se nærmere på begrepet som mange har et intuitivt forhold til. Vi går inn i tabell 1 og ser at i alt 4645 personer fikk ramipril $(4628+17) .17$ av dem som fikk ramipril døde, det vil si at risikoen for å $d ø$ var 0,37 prosent (17/4645). Tilsvarende var risikoen for å dø 0,95 prosent (44/4652) blant dem som tilhørte placebogruppen. For hvert av disse risikoestimatene kan vi beregne konfidensintervall som sier noe om hvilket svar vi kunne forventet å få hvis vi hadde gitt medisin eller narremedisin til hele den aktuelle populasjonen istedenfor et lite utvalg, som vi jo har diskutert tidligere (2).

\section{> ABSOLUTT RISIKOREDUKSJON}

Når vi sammenlikner risiko mellom grupper ønsker vi å beregne et tall som viser størrelsen på en eventuell forskjell. I eksempelet med ramipril (tabell 1) gjør vi det ved å trekke risikoen for å dø av hjerneslag i henholdsvis narremedisin 10,95 prosent) og ramipril $(0,37$ prosent) fra hverandre. Tallet vi ender opp med 0,95 prosent-0,37 prosent $=0,58$ prosent) kalles absolutt risikoreduksjon (ARR), og forskjellen mellom gruppene er mindre dess nærmere ARR er null. For å se om en eventuell forskjell kan forklares av tilfeldige feilkilder liker vi, som alltid, å beregne et konfidensintervall. Her går vi ikke nærmere inn på hvordan dette gjøres, og nøyer oss med å oppsummere at ARR med tilhørende konfidensintervall i vårt eksempel er 0,6 prosent (95 prosent KI 0,3-0,9).

\section{$>$ NNT}

NNT er nært beslektet med absolutt risikoreduksjon og står for «Number Needed to Treat». Vi beregner NNT som 1/ARR, og i vårt eksempel er NNT altså cirka 167. Fordelene med å bruke NNT er at denne størrelsen har en intuitiv fortolkning. Tallet sier hvor mange som må behandles for å unngå utfallet hos én pasient. NNT på 167 kan fortolkes som at 167 pasienter må få ramipril gjennom fire år for å unngå ett hjerneslagsrelatert dødsfall.

\section{> RISIKO RATIO}

Absolutt risikoreduksjon bestemmes av differansen mellom risiko i to ulike grupper, men en forskjell mellom to grupper kan også framkomme hvis vi deler risikoen for å dø i intervensjonsgruppen på tilsvarende risiko i placebogruppen. Hvis du gjør denne øvelsen får du vite at risiko ratio (RR), også kalt relativ risiko, er 0,37 prosent/0,95 prosent $=0,39$ med et 95 prosent konfidensintervall som strekker seg fra 0,22 til 0,68. Hvis hele den aktuelle populasjonen hadde fått ramipril så ville risikoen for dødelig hjerneslag med 95 prosent sannsynlighet vært mellom 0,22 og 0,68 ganger mindre enn hvis den samme populasjonen hadde fått narremedisin.

Generelt kan vi si at forskjellen mellom to grupper er liten så lenge risiko ratio (RR) er nær én. Hvordan du skal fortolke risiko ratioer vil imidlertid variere. Så lenge vi snakker om en negativ risiko (for eksempel risiko for død) vil små RR (mindre enn én) vise fordel i favør av intervensjonsgruppen. I statistikken snakker vi imidlertid også om positiv risiko som vi ser eksempel på i tabell 2. Tabell 2 tar utgangspunkt i en studie som undersøkte om et undervisningsprogram fikk flere nybakte mødre til å amme (5). Her ser man altså på risiko for at mødre velger å amme. Siden amming er en ønsket hendelse vil store RR (større enn én) gå i favør av intervensjonsgruppen. 
TABELL 2: Eksempel på en 2×2 tabell basert på en RCT med 108 deltakere som unders $\varnothing$ ker effekt av et undervisningsprogram som skal få flere nybakte mødre til å amme (5). For å se om undervisningen virker teller vi opp og sammenligner hvor mange som ammer i hver av de to gruppene. Risiko for å amme er det vi kan kalle en positiv risiko, siden dette er hendelser vi ønsker mange av.

\section{Behandling}

\begin{tabular}{llrr}
\hline & & $\begin{array}{r}\text { Under- } \\
\text { visning }\end{array}$ & Kontroll \\
Status & Ammer & 31 & 18 \\
& Ammerikke & 20 & 39 \\
\hline
\end{tabular}

\section{> ODDS RATIO}

Odds ratio (OR) er i likhet med RR et relativt mål, men istedenfor å sammenlikne risiko for en hendelse i to grupper sammenliknes oddsen for den samme hendelsen. I vårt første eksempel (tabell 1) er oddsen for slagrelatert død 0,0037 i ramiprilgruppen (17/4628) og 0,0095 i placebogruppen (44/4608), som betyr at odds ratio er 0,0037/0,0095 =0,39. Her gir OR altså akkurat samme svar som RR.

Basert på tabell 2 kan vi regne ut at OR er 3,4 mens tilsvarende RR er 1,9. Både OR og RR peker således i retning av at undervisningsprogrammet virker, men verdiene er forskjellig og gir ulike inntrykk av effektens størrelse. Selv om RR og OR ofte gir samme svar er det viktig å merke seg at RR og OR er ulike størrelser som kan gi ulike svar. Forskjellen mellom RR og OR blir stor hvis man ser på hendelser som opptrer hyppig (6).

\section{> ABSOLUTTE VERSUS RELATIVE MÅL}

Over har vi beskrevet ulike effektmål, og kanskje har du allerede lagt merke til at svarene spriker. Rett nok viser både ARR og RR at det er større forskjeller mellom ramipril og placebogruppen enn vi kan forklare med tilfeldigheter. Det er en forskjell mellom gruppene, men ARR og RR gir ulike inntrykk av hvor stor forskjellen er. På den ene siden ser vi at den absolutte risikoen går ned med 0,6 prosent. Relativt sett reduseres risikoen fra 0,95 til 0,37 som betyr en reduksjon på 61 prosent. Ingen av måtene er feil, men de skaper helt ulike inntrykk av størrelsen på forskjellen.

Det er viktig å være klar over denne forskjellen mellom absolutte og relative mål. Dette gjelder spesielt hvis utgangsrisikoen (risiko for en hendelse i kontrollgruppen) er lav, og man bør derfor alltid se risiko ratio i sammenheng med den absolutte risikoreduksjonen $(7,8)$.

\section{REFERANSER}

1. Brurberg KG, Hammer HL. Hvorfor trenger vi statistikk? Sykepleien Forskning. 2013;8:78-82.

2. Brurberg KG, Hammer HL. Hvorfor sammenlikne statistisk? Sykepleien Forskning. 2013;8:174-7.

3. Brurberg KG, Hammer HL. Hypotesetesting. Sykepleien Forskning. 2013;8:267-9.

4. Bosch J, Yusuf S, Pogue J, Sleight P et al. Use of ramipril in preventing stroke: double blind randomised trial. BMJ. 2002;324:699-702

5. Brent NB, Redd B, Dworetz A, D'Amico F, Greenberg JJ. Breast-feeding in a low-income population. Program to increase incidence and duration. Arch Pediatr Adolesc Med. 1995; 149:798-803

6. Davies HTO, Crombieb IK, Tavakoli M. When can odds ratios mislead? BMJ 1998;316:989.

7. King NB, Harper S, Young ME. Use of relative and absolute effect measures in reporting health inequalities: structured review. BMJ 2012;345:e5774.

8. Malenka DJ, Baron JA, Johansen S, Wahrenberger JW, Ross JM. The framing effect of relative and absolute risk. J Gen Intern Med 1993;8:543-8. 